\title{
Deoxyribonucleic Acid Relatedness and Phenotypic Characterization of Flexibacter columnaris sp. nov., nom. rev., Flexibacter psychrophilus sp. nov., nom. rev., and Flexibacter maritimus Wakabayashi, Hikida, and Masumura 1986
}

\author{
JEAN-FRANCOIS BERNARDET ${ }^{1 *}$ AND PATRICK A. D. GRIMONT ${ }^{2}$ \\ Laboratoire d'Ichtyopathologie, Institut National de la Recherche Agronomique, Station de Virologie Immunologie \\ Moléculaires, Centre de Recherches de Jouy-en-Josas, Domaine de Vilvert, 78350 Jouy-en-Josas, France ${ }^{1}$; and Unité des \\ Entérobactéries, Institut National de la Santé et de la Recherche Médicale, Unité 199, Institut Pasteur, F-75724 Paris
} Cédex 15 , France ${ }^{2}$

\begin{abstract}
Eight unidentified fish pathogens and 10 strains received as "Flexibacter columnaris," "Cytophaga psychrophila," and Flexibacter maritimus were compared with the type strains of all previously described species in the genera Cytophaga and Flexibacter and with seven Flavobacterium species by determining levels of deoxyribonucleic acid (DNA) relatedness (S1 nuclease method) and by performing phenotypic tests. The name Flexibacter columnaris sp. nov. is revived for a DNA relatedness group comprising eight strains that are 75 to $100 \%$ related to strain TG $39 / 87$ and 0 to $8 \%$ related to all of the other species studied. These strains produce flat rhizoid colonies which adhere to agar, show strong gliding movement, absorb Congo red, reduce nitrate to nitrite, and produce $\mathrm{H}_{2} \mathrm{~S}$. The guanine-plus-cytosine content of the DNA is $32 \mathrm{~mol} \%$. The type strain is strain NCMB 2248 (= ATCC 23463). The name Flexibacter psychrophilus sp. nov. is revived for a DNA relatedness group comprising seven strains that are 90 to $100 \%$ related to strain $N C M B 1947^{\mathrm{T}}(\mathrm{T}=$ type strain) and 0 to $5 \%$ related to all of the other species studied. These strains produce circular, convex colonies that have regular or spreading margins and do not adhere to agar, show very slow gliding movement, do not absorb Congo red, do not reduce nitrate, and do not produce $\mathrm{H}_{2} \mathrm{~S}$. The guanine-plus-cytosine content of the DNA is 33 mol\%. The type strain is strain NCMB 1947. Both $F$. columnaris and $F$. psychrophilus produce the flexirubin type of pigments, are strongly proteolytic, and do not hydrolyze (or produce acid from) any carbohydrate. Flexibacter maritimus (three strains) was shown to constitute a DNA relatedness group that is 0 to $8 \%$ related to all of the other species tested. Furthermore, this organism can be differentiated by phenotypic tests. The presence of $F$. maritimus in Europe is shown for the first time.
\end{abstract}

Since they were first described by Davis in 1922 (9), bacteria that are pathogenic for fish and belong to the order Cytophagales have frequently been isolated from diseased marine and freshwater fishes worldwide (1). These organisms have been responsible for substantial fish mortality and economic losses.

The class Flexibacteriae has recently been defined by Reichenbach and Dworkin (25) to include unicellular bacteria that are capable of gliding movement on wet surfaces (gliding bacteria) but are devoid of flagella. This class is composed of two orders; the members of the order Myxobacterales have high deoxyribonucleic acid (DNA) guanineplus-cytosine $(\mathrm{G}+\mathrm{C})$ contents $(67$ to $71 \mathrm{~mol} \%)$ and a typical life cycle with fruiting bodies and microcysts, and the members of the order Cytophagales have lower $\mathrm{G}+\mathrm{C}$ contents with a very wide range ( 28 to $67 \mathrm{~mol} \%)$, reflecting the heterogeneity of these organisms, and do not produce fruiting bodies.

The gliding bacteria isolated from diseased fish belong to the order Cytophagales and to the genera Flexibacter and Cytophaga. However, the taxonomy of these groups remains in a state of confusion. One of the main problems is the relationship of these organisms to the genus Flavobacterium; the phenotypic characteristics and $\mathrm{G}+\mathrm{C}$ contents of the DNAs are rather similar, and the published data concerning DNA or ribonucleic acid relatedness are not com-

\footnotetext{
* Corresponding author
}

prehensive enough to allow clear distinction between the two groups $(7,24,29)$. The feature considered to be of major importance is that members of the order Cytophagales are capable of gliding, whereas Flavobacterium species are not. However, the taxonomic reliability of gliding is uncertain (26). Thus, several authors prefer to use the name "Flavobacterium-Cytophaga group" and think that these bacteria should be studied together (13). Another very important problem concerns the definitions of the genera Cytophaga and Flexibacter and the distinction between these two taxa (26).

Among the members of the order Cytophagales isolated from diseased fish, the following three species are considered to be pathogenic: "Flexibacter columnaris," " $C y$ tophaga psychrophila," and Flexibacter maritimus.

In 1922, Davis (9) observed in the external lesions of diseased fish a bacterium which he named "Bacillus columnaris." Ordal and Rucker (21) isolated this organism and classified it among the "gliding bacteria" under the name "Chondrococcus columnaris" because they thought that microcysts and fruiting bodies were produced. Garnjobst (11) isolated this bacterium in 1945, found it to be devoid of fruiting bodies and microcysts, and renamed it "Cytophaga columnaris." In Bergey's Manual of Determinative Bacteriology, 8th ed., Leadbetter (16) considered this organism a true species of the genus Flexibacter and thus changed its name to "Flexibacter columnaris." This name was not listed on the Approved Lists of Bacterial Names (30) and has not 
been validated since 1980 by publication or announcement in the International Journal of Systematic Bacteriology. The disease caused by "Flexibacter columnaris" is called columnaris disease. It occurs worldwide in numerous species of freshwater fish where the water temperature exceeds $14^{\circ} \mathrm{C}$. The infection may be restricted to the gills or body surface, causing extensive necrosis and ulcers, or it may be generalized (3).

"Cytophaga psychrophila" was discovered by Davis in diseased fish in 1946 (10). Borg (A. F. Borg, Ph.D. thesis, University of Washington, Seattle, 1948) isolated this bacterium, named it (5), and studied the disease which it provokes. Leadbetter (16) considered this species to be incertae sedis, close to the genus Flexibacter. The name "Cytophaga psychrophila" did not appear on the Approved Lists (30) and has not been validated since 1980 . The disease which this organism induces in fish is called cold-water disease or low-temperature disease, because it occurs where the water temperature is below $15^{\circ} \mathrm{C}$. It is restricted to salmonids, and until now it has been reported only in the northern states of the United States and in Canada. Fry and young fish are preferentially infected, but adults are also susceptible. Various clinical signs may occur, the most frequent being erosions of the peduncle area (hence, the name peduncle disease, which is sometimes given to the disease) (R. A. Holt, M.Sc. and Ph.D. theses, Oregon State University, Corvallis, 1972 and 1987).

Flexibacter maritimus has recently been isolated from several species of marine fish reared in seawater in Japan. This new species has been validly published (32). Infected fish have eroded mouths and fins and ulcerated skin lesions (31).

"Flexibacter columnaris" (4) and "Cytophaga psychrophila" (J. F. Bernardet and B. Kerouault, Appl. Environ. Microbiol., in press) were recently isolated in France for the first time. In this study, French isolates were compared with isolates from other countries, with the type strains of each valid species belonging to the genera Flexibacter and $C y$ tophaga, and with seven Flavobacterium species. The two strains of Flexibacter maritimus deposited in the National Collection of Marine Bacteria (NCMB), Aberdeen, Scotland, were included in the study and compared with a "Flexibacter columnaris"'-like bacterium (strain NCMB 2158) that was isolated from marine fish in Scotland (8). The results of our phenotypic and DNA relatedness studies indicate that these three fish-pathogenic bacteria are independent species. Consequently, the names Flexibacter columnaris and Flexibacter psychrophilus are revived, and the identification of strain NCMB 2158 as Flexibacter maritimus proves the presence of this species in Europe for the first time.

\section{MATERIALS AND METHODS}

Bacterial strains. The bacterial strains which we studied are listed in Table 1. The type strains of the valid species of the genera Flexibacter and Cytophaga and the seven Flavobacterium species were obtained from collections, and other strains were isolated from diseased fish in France and in other countries.

Most bacterial strains were grown in Anacker-Ordal (2) broth or agar, which contain (per liter) $0.5 \mathrm{~g}$ of tryptone (Difco Laboratories, Detroit, Mich.), $0.5 \mathrm{~g}$ of yeast extract (Difco), $0.2 \mathrm{~g}$ of sodium acetate (Prolabo, Paris, France), and $0.2 \mathrm{~g}$ of beef extract (Difco); Anacker-Ordal agar also contains $9 \mathrm{~g}$ of agar (Difco) per liter. The $\mathrm{pH}$ was adjusted to 7.2 to 7.4 .
Some strains, which did not grow on the media described above, were grown on other media. Cytophaga hutchinsonii was grown in Dubos medium (26) supplemented with $30 \%$ (wt/vol) D-cellobiose; Flexibacter roseolus and Flexibacter ruber were grown in nutrient agar and in nutrient broth (Oxoid Ltd., London, England). All of the marine species, except Flexibacter polymorphus and Cytophaga latercula, were grown in Anacker-Ordal broth and Anacker-Ordal agar prepared with artificial seawater (26) instead of distilled water; Flexibacter polymorphus was cultivated on Flexibacter medium (17), and Cytophaga latercula was cultivated on a medium for marine flexibacteria (18). Flavobacterium odoratum, Flavobacterium breve, Flavobacterium spiritivorum, Flavobacterium meningosepticum, and Flavobacterium multivorum were grown in Trypticase soy agar and broth (bioMérieux, Charbonnières-les-Bains, France).

Most strains were cultivated at $22^{\circ} \mathrm{C}$, with the following exceptions: "Cytophaga psychrophila," 18 to $20^{\circ} \mathrm{C}$; Flexibacter roseolus, Flexibacter ruber, and most marine species, $25^{\circ} \mathrm{C}$; Flexibacter polymorphus, Flavobacterium odoratum, Flavobacterium breve, and Flavobacterium spiritivorum, $30^{\circ} \mathrm{C}$; and Flavobacterium meningosepticum and Flavobacterium multivorum, $37^{\circ} \mathrm{C}$.

DNA-DNA hybridization. We used previously described methods to extract, purify, and shear unlabeled DNAs (6). The exact procedures used for in vitro labeling of DNA (nick translation) with tritium-labeled nucleotides (Amersham International, Amersham, England) and for hybridization experiments (S1 nuclease-trichloroacetic acid method) have been described previously (12).

G $+\mathbf{C}$ content of DNA. The melting temperatures $\left(T_{m}\right)$ of $50-\mu \mathrm{g} / \mathrm{ml}$ DNA solutions in $0.1 \times \mathrm{SSC}$ buffer $(1 \times \mathrm{SSC}$ is 0.15 $\mathrm{M} \mathrm{NaCl}$ plus $0.015 \mathrm{M}$ trisodium citrate) were determined optically by thermal denaturation (20) with a spectrophotometer (Gilford Instrument Laboratories, Inc., Oberlin, Ohio). The $\mathrm{G}+\mathrm{C}$ contents of DNAs were determined from melting temperatures by using the following equation of Owen et al. (22): $\mathrm{G}+\mathrm{C}$ content $=\left(2.08 \times T_{m}\right)-106.4$. The DNA of Escherichia coli $\mathrm{K}-12$ was used as a standard ( $\mathrm{G}+\mathrm{C}$ content, $50.6 \mathrm{~mol} \%$ ); in all cases, it was dialyzed together with the DNAs to be tested against the same buffer solution in the same flask to avoid any difference in salt concentration.

Morphological and physiological studies. The morphological and physiological studies were performed as described elsewhere (4). The morphology of colonies on solid medium was studied by visual observation and by light microscopy (magnification, $\times 20$ ). Gliding movement was checked under a microscope (magnification, $\times 100$ ) by using a hanging drop preparation of a 48-h broth culture; the bacterial cells were observed under a microscope (magnification, $\times 100$ ) after Gram staining. The tolerance of the strains to different temperatures $(3,6,10,12,15,18,20,22,25,28,30,33,35$, 37 , and $\left.40^{\circ} \mathrm{C}\right)$ and to different $\mathrm{NaCl}$ concentrations $(0.5,1,2$, and $3 \%$, wt/vol) was studied in the liquid medium used for growing each strain (see above) and in Trypticase soy broth.

Biochemical tests. Biochemical characteristics were determined as previously described (4). Tests were performed at the temperatures and in the media selected for the growth of each strain (see above).

In addition, deoxyribonuclease was tested by spot inoculation of agar containing DNA (Diagnostics Pasteur, Marnesla-Coquette, France); DNA hydrolysis was visualized by flooding the plate with $1 \mathrm{~N} \mathrm{HCl}$. Production of acid from carbohydrates was tested by using API $50 \mathrm{CH}$ galleries (API System, La Balme-les-Grottes, France) and ammonium salt- 
TABLE 1. Bacterial strains included in this study

\begin{tabular}{|c|c|c|}
\hline Name as received & Strain $^{a}$ & Source \\
\hline Cytophaga aquatilis & DSM $2063^{\mathrm{T}}$ & Gills of diseased salmon, Michigan \\
\hline Cytophaga arvensicola & JCM $2836^{\mathrm{T}}$ & Soil, Osaka, Japan \\
\hline Cytophaga fermentans ${ }^{b}$ & NCMB $2218^{\mathrm{T}}$ & Marine mud, California \\
\hline Cytophaga flevensis & DSM $1076^{\mathrm{T}}$ & Lake Ijsselmeer, The Netherlands \\
\hline Cytophaga heparina & NCIB $9290^{\mathrm{T}}$ & Soil \\
\hline Cytophaga hutchinsonii & NCIB $9469^{\mathrm{T}}$ & Soil \\
\hline \multirow[t]{3}{*}{ Cytophaga johnsonae } & DSM $2064^{T}$ & Soil or mud, Rothamsted or Cambridge, England \\
\hline & ATCC 29585 & Diseased freshwater fish, Manitoba, Canada \\
\hline & ATCC 29586 & Diseased freshwater fish, Manitoba, Canada \\
\hline Cytophaga latercula ${ }^{b}$ & NCMB $1399^{\mathrm{T}}$ & Outflow of marine aquarium, California \\
\hline Cytophaga lytica ${ }^{b}$ & NCMB $1423^{T}$ & Beach mud, Limon, Costa Rica \\
\hline Cytophaga salmonicolor ${ }^{b}$ & NCMB $2216^{\mathrm{T}}$ & Marine mud, California \\
\hline "Cytophaga allerginae" & ATCC 35408 & Water in industrial air-cooling unit, United States \\
\hline Flexibacter aggregans ${ }^{b}$ & NCMB $1443^{T}$ & Beach sand, Tema, Ghana \\
\hline \multirow[t]{2}{*}{ Flexibacter aurantiacus } & NCMB $1382^{\mathrm{T}}$ & Garden soil, Minnesota \\
\hline & NCMB 1455 & United States \\
\hline Flexibacter canadensis & ATCC $29591^{\mathrm{T}}$ & Soil, Canada \\
\hline Flexibacter flexilis & NCMB $1377^{\mathrm{T}}$ & Lily pond, San Jose, Costa Rica \\
\hline Flexibacter litoralis ${ }^{b}$ & NCMB $1366^{\mathrm{T}}$ & Outflow of marine aquarium, California \\
\hline Flexibacter polymorphus ${ }^{b}$ & ATCC $27820^{\mathrm{T}}$ & Decaying ascidian, La Paz, Mexico \\
\hline Flexibacter roseolus & NCMB $1433^{\mathrm{T}}$ & Hot spring, Agua Caliente, Costa Rica \\
\hline Flexibacter ruber & NCMB $1436^{\mathrm{T}}$ & Hot spring, Geysir, Iceland \\
\hline Flexibacter sancti & NCMB $1379^{\mathrm{T}}$ & Buenos Aires, Argentina \\
\hline Flexibacter tractuosus ${ }^{b}$ & NCMB $1408^{\mathrm{T}}$ & Sand, Nhatrang, Vietnam \\
\hline \multirow[t]{2}{*}{ Flexibacter maritimus ${ }^{b}$} & NCMB $2154^{\mathrm{T}}$ & Diseased red sea bream (Pagrus major) kidney, Hiroshima, Japan \\
\hline & NCMB 2153 & $\begin{array}{l}\text { Diseased black sea bream (Acanthopagrus schlegeli) kidney, } \\
\text { Hiroshima, Japan }\end{array}$ \\
\hline Flavobacterium aquatile & NCIB $8694^{\mathrm{T}}$ & Deep well, Kent, England \\
\hline Flavobacterium balustinum & LA $724^{\mathrm{T}}$ & Heart blood of fish, France \\
\hline Flavobacterium breve & NCTC $11099^{\mathrm{T}}$ & Human bronchial secretion, Switzerland \\
\hline Flavobacterium meningosepticum & NCTC $10016^{\mathrm{T}}$ & Cerebrospinal fluid from premature infant, United States \\
\hline Flavobacterium odoratum & NCTC $11036^{\mathrm{T}}$ & Unknown \\
\hline Flavobacterium multivorum & NCTC $11343^{\mathrm{T}}$ & Human spleen, Washington, D.C. \\
\hline Flavobacterium spiritivorum & NCTC $11386^{\mathrm{T}}$ & Human uterus, Kansas \\
\hline \multirow[t]{6}{*}{ "Flexibacter columnaris" } & NCMB 1038 & Salmonid, United States \\
\hline & NCMB $2248^{\mathrm{T}}$ & Morphological variant of strain NCMB 1038 \\
\hline & Holt DD3-69 & Adult chinook salmon (Oncorhynchus tshawytscha) gill lesions, Oregon \\
\hline & Holt IC8-69 & Young catfish (Ictalurus sp.) kidney, Idaho \\
\hline & Wakabayashi EK28 & Japanese eel (Anguilla japonica) gill lesions, Japan \\
\hline & Farkas $\mathrm{H} 82 / 7$ & Carp (Cyprinus carpio) skin ulcer, Hungary \\
\hline \multirow[t]{2}{*}{ "Cytophaga psychrophila", } & NCMB $1947^{\mathrm{T}}$ & Coho salmon (Oncorhynchus kisutch) kidney, Washington \\
\hline & Holt SH3-81 & Coho salmon kidney, Oregon \\
\hline \multirow[t]{8}{*}{ Unidentified isolates } & TG $39 / 87$ & Adult black bullhead (Ictalurus melas) skin ulcer, France \\
\hline & TG 44/87 & Brown trout fry (Oncorhynchus mykiss) skin lesions, France \\
\hline & TG 02/86 & Rainbow trout fry (Salmo gairdneri) kidney, France \\
\hline & TG $28 / 86$ & Adult rainbow trout skin lesions, France \\
\hline & LNPAA P01/88 & Rainbow trout fry spleen, France \\
\hline & TG P02/88 & Rainbow trout fry spleen, France \\
\hline & LNPAA P03/88 & Rainbow trout fry spleen, France \\
\hline & NCMB $2158^{b, c}$ & Dover sole (Solea solea) skin lesions, Scotland \\
\hline
\end{tabular}

"ATCC, American Type Culture Collection, Rockville, Md.; NCIB and NCMB, National Collection of Industrial and Marine Bacteria, Aberdeen, Scotland; DSM, Deutsche Sammlung von Mikroorganismen, Göttingen, Federal Republic of Germany; JCM, Japanese Collection of Microorganisms, Tokyo, Japan; LA, Centre de Collection des Types Microbiens, Lausanne, Switzerland; NCTC, National Collection of Type Cultures, London, England; Holt, R. A. Holt, Department of Microbiology, Oregon State University, Corvallis; Wakabayashi, H. Wakabayashi, Department of Fisheries, Faculty of Agriculture, University of Tokyo, Tokyo, Japan; Farkas, J. Farkas, Fisheries Research Institute, Szarvas, Hungary; TG, Laboratoire d'Ichtyopathologie, Institut National de la Recherche Agronomique, Thiverval-Grignon, France; LNPAA, Laboratoire National de Pathologie des Animaux Aquatiques, IFREMER, Centre de Brest, Plouzané, France.

${ }^{b}$ Halophile or marine species requiring media supplemented with $\mathrm{NaCl}$ or seawater for growth

c Strain NCMB 2158 (a Flexibacter species) was isolated by A. C. Campbell and J. A. Buswell, Department of Biology, Paisley College of Technology, Paisley, Scotland.

sugar broth. Hydrolysis of 19 substrates was tested by using API ZYM galleries incubated at the temperature selected for each strain; previous trials (Bernardet, unpublished data) showed that incubation for $12 \mathrm{~h}$ was preferable when the temperature was 18 to $30^{\circ} \mathrm{C}$ instead of $37^{\circ} \mathrm{C}$. Hydrolysis of a given substrate resulted in production of a given color, whose intensity was scored on a scale from 1 to 5 .

\section{RESULTS}

DNA-DNA hybridization. The DNA relatedness results obtained with labeled reference DNAs from strains TG 39/87, NCMB $1947^{\mathrm{T}}$, and NCMB 2153 are shown in Table 2.

Strain TG $44 / 87$ and the six "Flexibacter columnaris" strains formed a tight genomic species, whose members 
TABLE 2. Levels of DNA relatedness among Flexibacter columnaris, Flexibacter psychrophilus, Flexibacter maritimus, and other species belonging to the genera Cytophaga, Flexibacter, and Flavobacterium

\begin{tabular}{|c|c|c|c|c|}
\hline \multicolumn{2}{|c|}{ Source of unlabeled DNA ${ }^{a}$} & \multicolumn{3}{|c|}{$\begin{array}{l}\% \text { Reassociation at } 60^{\circ} \mathrm{C} \\
\text { with labeled DNA from: }\end{array}$} \\
\hline Species or group & Strain & $\begin{array}{c}\text { Strain } \\
\text { TG } \\
39 / 87\end{array}$ & $\begin{array}{l}\text { Strain } \\
\text { NCMB } \\
1947^{\mathrm{T}}\end{array}$ & $\begin{array}{c}\text { Strain } \\
\text { NCMB } \\
2153\end{array}$ \\
\hline \multirow[t]{8}{*}{ Flexibacter columnaris } & TG $39 / 87$ & $100^{b}$ & 3 & 0 \\
\hline & NCMB 1038 & 95 & 4 & 0 \\
\hline & NCMB $2248^{\mathrm{T}}$ & 99 & 3 & 0 \\
\hline & Holt DD3-69 & 87 & 2 & 8 \\
\hline & Holt IC8-69 & 76 & 2 & 0 \\
\hline & $\begin{array}{l}\text { Wakabayashi } \\
\text { EK28 }\end{array}$ & 78 & 3 & 0 \\
\hline & Farkas $\mathrm{H} 82 / 7$ & 96 & 3 & 0 \\
\hline & TG $44 / 87$ & 101 & 3 & 0 \\
\hline \multirow{7}{*}{$\begin{array}{l}\text { Flexibacter psychro } \\
\text { philus }\end{array}$} & NCMB $1947^{\mathrm{T}}$ & 4 & 100 & 0 \\
\hline & Holt SH3-81 & 2 & 92 & 5 \\
\hline & TG $02 / 86$ & 4 & 103 & 0 \\
\hline & TG $28 / 86$ & 3 & 105 & 0 \\
\hline & LNPAA P01/88 & 2 & 105 & 1 \\
\hline & TG P02/88 & 2 & 107 & 1 \\
\hline & LNPAA P03/88 & 3 & 90 & 1 \\
\hline \multirow[t]{3}{*}{ Flexibacter maritimus } & NCMB 2153 & 1 & 3 & 100 \\
\hline & NCMB $2154^{\mathrm{T}}$ & 1 & 1 & 73 \\
\hline & NCMB 2158 & 2 & 2 & 77 \\
\hline $\begin{array}{l}\text { Cytophaga spp. } \\
{\text { (13 strains })^{c}}^{c}\end{array}$ & & 1 to 6 & 0 to 3 & 0 to 8 \\
\hline $\begin{array}{l}\text { Flexibacter spp. } \\
\quad(11 \text { strains })^{d}\end{array}$ & & 0 to 2 & 0 to 5 & 0 \\
\hline $\begin{array}{l}\text { Flavobacterium spp. } \\
\text { (7 strains })^{e}\end{array}$ & & 1 to 9 & 0 to 3 & 0 to 6 \\
\hline
\end{tabular}

a Abbreviations are explained in Table 1, footnote $a$.

${ }^{b}$ The values are percentages of relatedenss.

${ }^{c}$ Cytophaga aquatilis DSM $2063^{\mathrm{T}}$. Cytophaga arvensicola JCM $2836^{\mathrm{T}}$ Cytophaga fermentans NCMB 2218 ${ }^{\mathrm{T}}$, Cytophaga flevensis DSM $1076^{\mathrm{T}}$. Cytophaga heparina NCIB $9290^{\mathrm{T}}$, Cytophaga hutchinsonii NCIB $9469^{\mathrm{T}}$, Cytophaga johnsonae DSM 2064 ${ }^{\mathrm{T}}$, ATCC 29585, and ATCC 29586, Cytoph aga latercula $\mathrm{NCMB} 1399^{\mathrm{T}}$, Cytophaga lytica $\mathrm{NCMB} 1423^{\mathrm{T}}$, Cytophaga salmonicolor NCMB $2216^{\mathrm{T}}$, and "Cytophaga allerginae" ATCC 35408.

${ }^{d}$ FLexibacter aggregans NCMB $1443^{\mathrm{T}}$, Flexibacter aurantiacus NCMB $1382^{\mathrm{T}}$ and NCMB 1455, FLexibacter canadensis ATCC $29591^{\mathrm{T}}$, Flexibacter flexilis NCMB $1377^{\mathrm{T}}$, Flexibacter litoralis $\mathrm{NCMB} 1366^{\mathrm{T}}$. Flexibacter polymorphus ATCC $27820^{\mathrm{T}}$, Flexibacter roseolus NCMB $1433^{\mathrm{T}}$, Flexibacter ruber NCMB $1436^{\mathrm{T}}$, Flexibacter sancti NCMB $1379^{\mathrm{T}}$, and Flexibacter tractuosus NCMB $1408^{1}$

e Flavobacterium aquatile NCIB $8694^{\mathrm{T}}$, Flavobacterium balustinum LA $724^{\mathrm{T}}$, Flavobacterium breve NCTC $11099^{\mathrm{T}}$, Flavobacterium meningosepticum NCTC $10016^{\mathrm{T}}$, Flavobacterium odoratum NCTC $11036^{\mathrm{T}}$, Flavobacterium multivorum NCTC $11343^{\mathrm{T}}$, and Flavobacterium spiritivorum NCTC $11386^{\mathrm{T}}$.

were more than $75 \%$ related to strain TG $39 / 87$ and only 0 to $9 \%$ related to all of the other organisms studied belonging to the genera Cytophaga, Flexibacter, and Flavobacterium.

Strain Holt SH3-81 and unidentified isolates TG 02/86, TG 28/86, LNPAA P01/88, TG P02/88, and LNPAA P03/88 also formed a tight genomic species, whose members were more than $90 \%$ related to "Cytophaga psychrophila" NCMB $1947^{\mathrm{T}}$ and only 0 to $5 \%$ related to all of the other organisms studied.

Flexibacter maritimus NCMB $2154^{\mathrm{T}}$ and unidentified Flexibacter sp. strain NCMB 2158 also formed a tight genomic species; they were more than $73 \%$ related to Flexibacter maritimus NCMB 2153 and only 0 to $8 \%$ related to all of the other organisms studied.

DNA base compositions. The base compositions of the three "Flexibacter columnaris" strains tested (strains
NCMB $2248^{\mathrm{T}}$, TG $39 / 87$ and TG $44 / 87$ ) were $32,32.3$, and $33.2 \mathrm{~mol} \% \mathrm{G}+\mathrm{C}$, respectively, and the base compositions of the three "Cytophaga psychrophila" strains tested (strains NCMB $1947^{\mathrm{T}}$, TG $02 / 86$, and LNPAA P01/88) were 32.5 , 33.8 , and $33.8 \mathrm{~mol} \% \mathrm{G}+\mathrm{C}$, respectively.

Phenotypic characteristics common to all strains. All of the strains studied were gram-negative rods that were devoid of flagella. The length of the Cytophaga and Flexibacter spp. cells was usually in the range from 3 to $10 \mu \mathrm{m}$, but there were wide variations depending on the age of the culture, the medium, and the temperature. The following species had exceptionally long or short cells: Flexibacter flexilis, 15 to 20 $\mu \mathrm{m} ;$ Cytophaga arvensicola and Flexibacter sancti, more than $30 \mu \mathrm{m}$; Flexibacter roseolus and Flexibacter ruber, 50 to $100 \mu \mathrm{m}$; Flexibacter polymorphus, filaments more than $100 \mu \mathrm{m}$ long; and Cytophaga heparina and Cytophaga flevensis, 0.5 to $1.5 \mu \mathrm{m}$. Flavobacterium meningosepticum and Flavobacterium odoratum had cell lengths ranging from 0.2 to $2 \mu \mathrm{m}$ and from 1 to $10 \mu \mathrm{m}$, respectively. The widths of the cells of all organisms were 0.3 to $0.5 \mu \mathrm{m}$.

Most strains belonging to the order Cytophagales exhibited gliding movement; gliding cells frequently bent and pivoted around one extremity fixed to the glass slide, and filamentous cells displayed active flexing movements. $C y$ tophaga heparina, Cytophaga flevensis, Cytophaga hutchinsonii, and Flexibacter sancti did not glide; "Cytophaga psychrophila" exhibited very slow gliding movement involving only a few cells in the microscope field. Gliding motility was never observed in Flavobacterium species.

The Flavobacterium spp. colonies were always circular and convex with entire margins and did not adhere to the agar. Most Cytophaga and Flexibacter spp. strains produced flat, irregular to rhizoid colonies with undulate to filamentous margins. The colonies of "Flexibacter columnaris" (with the exception of strain NCMB 1038) adhered strongly to the agar, while Flexibacter maritimus and Flexibacter sancti colonies adhered moderately to the agar. The species belonging to the order Cytophagales frequently formed swarms which spread on the agar. The colonies of " Cytophaga psychrophila" were circular and convex with regular or spreading margins. Most strains produced a cream of yellow nondiffusible pigment, with the following notable exceptions: Flexibacter roseolus and Flexibacter ruber, bright orange pigment; Cytophaga salmonicolor and Flexibacter litoralis, pink pigment; and Cytophaga latercula, bright red pigment.

All strains were strictly aerobic and oxidase positive and hydrolyzed tributyrin. Cytophaga hutchinsonii was the only species that digested cellulose. Skim milk agar was cleared by all strains except Cytophaga heparina and Cytophaga hutchinsonii strains. Tween 20 was hydrolyzed by all strains except the Cytophaga hutchinsonii strain, and Tween 80 was hydrolyzed by all strains except Cytophaga flevensis, $C y$ tophaga hutchinsonii, Cytophaga arvensicola, and Cytophaga fermentans strains. A total of 26 strains did not grow in decarboxylase liquid media, and the 46 other strains gave negative or uninterpretable results.

All strains grew in the liquid media selected for growth at 22 and $25^{\circ} \mathrm{C}$. Most strains that grew in the presence of $2 \%$ $\mathrm{NaCl}$ were able to grow in the presence of $3 \% \mathrm{NaCl}$; exceptions were Cytophaga aquatilis, Cytophaga arvensicola, Cytophaga johnsonae DSM 2064 ${ }^{\mathrm{T}}$, Flavobacterium meningosepticum, and Flavobacterium multivorum.

Antibiotic susceptibility was highly variable among the strains, but all strains were resistant to gentamicin and polymyxin B (no inhibition around disks). 
TABLE 3. Differential characteristics of Cytophaga, Flexibacter and Flavobacterium species

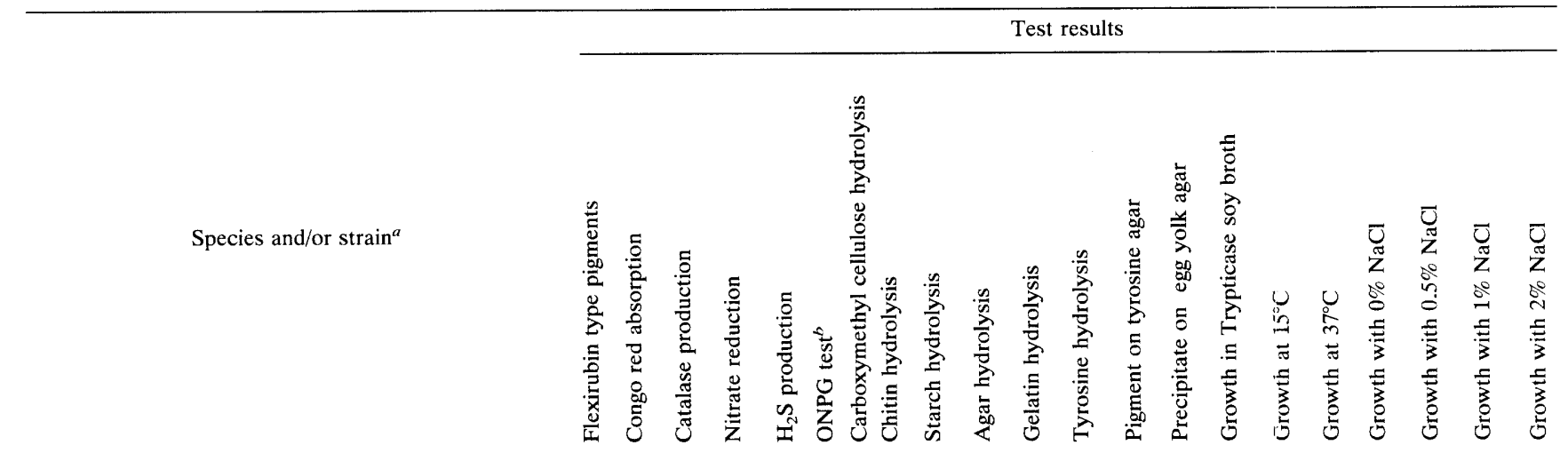

Flexibacter columnaris (8 strains)

Flexibacter psychrophilus (7 strains)

Flexibacter maritimus (3 strains)

Cytophaga aquatilis DSM $2063^{\mathrm{T}}$

Cytophaga arvensicola JCM $2836^{\mathrm{T}}$

Cytophaga fermentans NCMB $2218^{\mathrm{T}}$

Cytophaga flevensis DSM $1076^{\mathrm{T}}$

Cytophaga heparina NCIB $9290^{\mathrm{T}}$

Cytophaga hutchinsonii NCIB $9469^{\mathrm{T}}$

Cytophaga johnsonae DSM $2064^{\mathrm{T}}$

Cytophaga johnsonae ATCC 29585

Cytophaga johnsonae ATCC 29586

Cytophaga latercula NCMB $1399^{\mathrm{T}}$

Cytophaga lytica NCMB $1423^{\mathrm{T}}$

Cytophaga salmonicolor NCMB $2216^{\mathrm{T}}$

"Cytophaga allerginae" ATCC 35408

Flexibacter aggregans NCMB $1443^{\mathrm{T}}$

Flexibacter aurantiacus NCMB $1382^{\mathrm{T}}$

Flexibacter aurantiacus NCMB 1455

Flexibacter canadensis ATCC $29591^{\mathrm{T}}$

Flexibacter flexilis NCMB $1377^{\mathrm{T}}$

Flexibacter litoralis NCMB $1366^{\mathrm{T}}$

Flexibacter polymorphus ATCC $27820^{\mathrm{T}}$

Flexibacter roseolus NCMB $1433^{\mathrm{T}}$

Flexibacter ruber NCMB $1436^{\mathrm{T}}$

Flexibacter sancti NCMB $1379^{\mathrm{T}}$

Flexibacter tractuosus NCMB $1408^{\mathrm{T}}$

Flavobacterium aquatile NCIB $8694^{\mathrm{T}}$

Flavobacterium balustinum LA $724^{\mathrm{T}}$

Flavobacterium breve NCTC $11099^{\mathrm{T}}$

Flavobacterium meningosepticum $\mathrm{NCTC}^{\mathrm{T}} 10016^{\mathrm{T}}$
Flavobacterium odoratum NCTC $11036^{\mathrm{T}}$

Flavobacterium multivorum NCTC $11343^{\mathrm{T}}$

Flavobacterium spiritivorum NCTC $11386^{\mathrm{T}}$

$+^{c}++++----2+-\mathrm{d}+-\mathrm{d} \mathrm{d}++-$

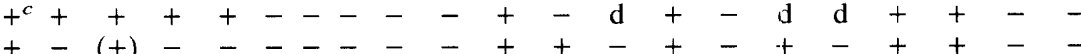

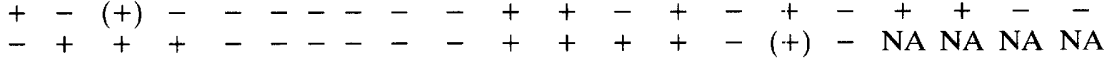

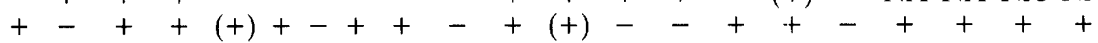

$+-(+)(+)-++-(+)-++-\infty+++++(+)$

$--_{-}-++-+++-t_{-}+\mathrm{NT}+-\mathrm{C}_{-}+$

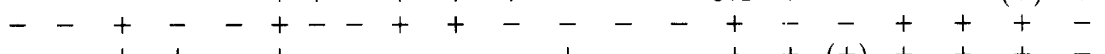

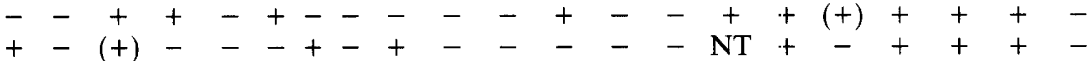

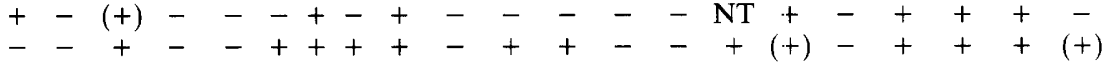

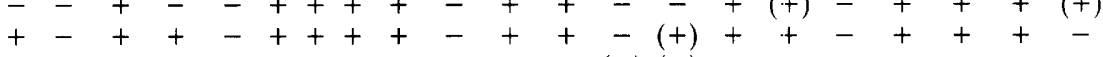

$+-++-++++-++(+)(+)++-+++$

$+?^{d}-++-+-++++t_{-}+\mathrm{NT}+-t_{-}+$

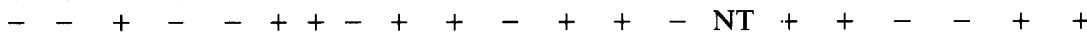

$--+-+++-+-+-t_{-}+\mathrm{NT}(+)+-t_{-}+$

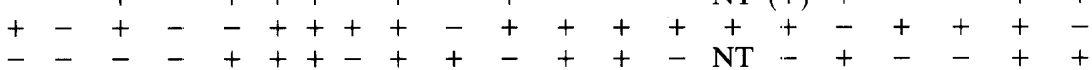

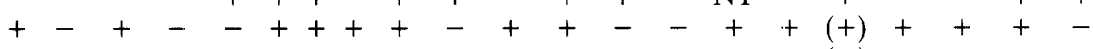

$+-+--++++-++-\infty+(+)+++$

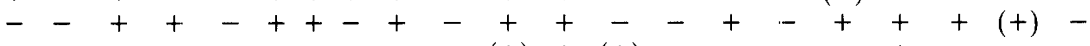

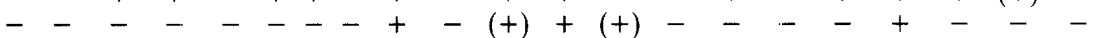

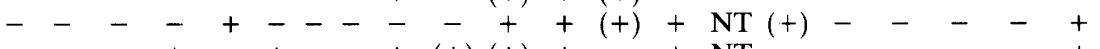

$---+-+--+(+)(+)+-+\mathrm{NT}--\mathrm{N}_{-}-+$

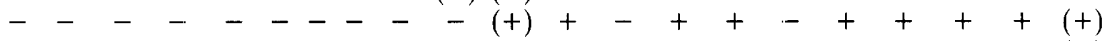

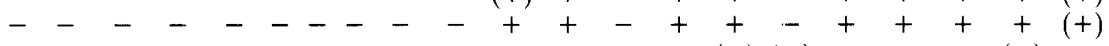

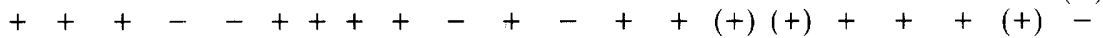

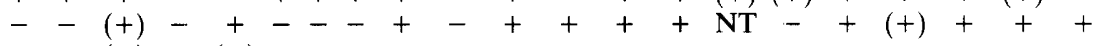

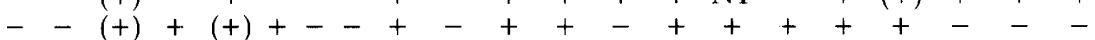

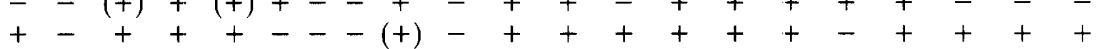

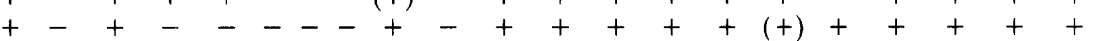

$--+-\infty+--_{-}+(+)(+)-+(+)+++++$

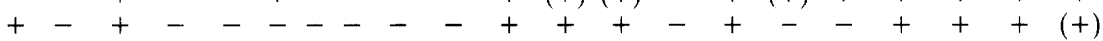

$--(+)(+)(+)+--+--(+)(+)-+(+)++++(+)$

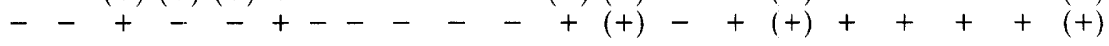

${ }^{a}$ Abbreviations are explained in Table 1, footnote $a$.

${ }^{b}$ ONPG, $o$-Nitrophenyl- $\beta$-D-galactopyranoside.

$c+$, All strains positive; -, all strains negative; $(+)$, weakly positive; d, different reactions; NT, not tested; NA, not applicable (no growth in Anacker-Ordal broth supplemented with only $\mathrm{NaCl}$ ).

${ }^{d}$ Undetermined due to the red coloration of colonies.

The following species did not produce acid from any carbohydrate (API 50CH galleries): "Flexibacter columnaris" (eight strains), "Cytophaga psychrophila" (seven strains), Flexibacter maritimus (three strains), Flexibacter roseolus, Flexibacter ruber, Flexibacter litoralis, and Flexibacter polymorphus. All of the other species tested produced acid from 4 to 34 carbohydrates in API $50 \mathrm{CH}$ galleries.

Other phenotypic properties which varied among the strains are shown in Tables 3 and 4.

Phenotypic characteristics of "Flexibacter columnaris." The properties that were common to the eight strains of "Flexibacter columnaris" are given below. The following properties varied among the strains: the aspect of the colonies on agar was more or less rhizoid; strains NCMB 1038, Farkas H82/7, Holt DD3, Holt IC8, TG 39/87, and TG 44/87 produced a brown color on tyrosine agar (probably due to an oxidized derivative of tyrosine); strains NCMB 1038, Holt DD3, and Wakabayashi EK28 were susceptible to sulfonamides; strains NCMB 1038, NCMB $2248^{\mathrm{T}}$, Wakabayashi EK28, TG 39/87, and TG 44/87 hydrolyzed $N$-benzoylDL-arginine-2-naphthylamide and $N$-glutaryl-phenylalanine2-naphthylamide in API ZYM galleries; and strains NCMB 1038 and NCMB $2248^{\mathrm{T}}$ did not grow at temperatures above $33^{\circ} \mathrm{C}$, and four other strains grew scantily at 35 and $37^{\circ} \mathrm{C}$.

Phenotypic characteristics of "Cytophaga psychrophila." 
TABLE 4. Enzymatic patterns of Cytophaga, Flexibacter and Flavobacterium species in API ZYM galleries

\begin{tabular}{|c|c|c|c|c|c|c|c|c|c|c|c|c|c|c|c|c|c|c|c|}
\hline \multirow{2}{*}{ Species and/or strain ${ }^{a}$} & \multicolumn{19}{|c|}{ Hydrolysis of the following substrates ${ }^{b}$ : } \\
\hline & A & B & $\mathrm{C}$ & $\mathrm{D}$ & $\mathrm{E}$ & $\mathrm{F}$ & G & $\mathrm{H}$ & I & $\mathrm{J}$ & $\mathrm{K}$ & $\mathrm{L}$ & M & $\mathrm{N}$ & $\mathrm{O}$ & $\mathrm{P}$ & Q & $\mathbf{R}$ & \\
\hline Flexibacter columnaris ( 8 strains) & $5^{c}$ & 2 & 3 & 0 & 4 & 4 & 1 & $\mathrm{D}^{d}$ & $\mathrm{D}^{d}$ & 3 & 3 & 0 & 0 & 0 & 0 & 0 & 0 & 0 & \\
\hline Flexibacter psychrophilus (7 strains) & 5 & 2 & 3 & 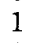 & 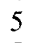 & 1 & 0 & 0 & 0 & 3 & 3 & 0 & 0 & 0 & 0 & 0 & 0 & 0 & \\
\hline Flexibacter maritimus (3 strains) & 5 & 3 & 4 & 1 & 5 & 5 & 3 & 1 & 2 & 5 & 5 & 0 & 0 & 0 & 0 & 0 & 0 & 0 & \\
\hline Cytophaga aquatilis DSM $2063^{\mathrm{T}}$ & 5 & 2 & 4 & 1 & 4 & 5 & 2 & 0 & 0 & 4 & 5 & 0 & 0 & 0 & 4 & 0 & 2 & 0 & \\
\hline Cytophaga arvensicola JCM $2836^{\mathrm{T}}$ & 5 & 2 & 3 & 1 & 5 & 5 & 2 & 4 & 1 & 4 & 4 & 3 & 4 & 0 & 4 & 3 & 5 & 2 & \\
\hline Cytophaga fermentans NCMB $2218^{\mathrm{T}}$ & 5 & 1 & 3 & 0 & 5 & 2 & 0 & 2 & 0 & 5 & 5 & 0 & 5 & 1 & 2 & 5 & 5 & 0 & \\
\hline Cytophaga flevensis DSM $1076^{\mathrm{T}}$ & 5 & 1 & 2 & 1 & 5 & 1 & 1 & 0 & 0 & 3 & 3 & 1 & 5 & 0 & 3 & 0 & 4 & 0 & \\
\hline Cytophaga heparina $\mathrm{NCIB} 9290^{\mathrm{T}}$ & 5 & 2 & 4 & 0 & 4 & 2 & 1 & 0 & 0 & 4 & 2 & 0 & 0 & 0 & 1 & 0 & 4 & 1 & \\
\hline Cytophaga hutchinsonii NCIB $9469^{\mathrm{T}}$ & 4 & 2 & 4 & 1 & 4 & 4 & 3 & 0 & 0 & 3 & 2 & 0 & 0 & 0 & 0 & 0 & 0 & 0 & \\
\hline Cytophaga johnsonae DSM $2064^{\mathrm{T}}$ & 5 & 1 & 3 & 1 & 5 & 5 & 2 & 1 & 1 & 4 & 5 & 0 & 3 & 0 & 4 & 1 & 4 & 0 & \\
\hline Cytophaga johnsonae ATCC 29585 & 5 & 3 & 4 & 1 & 4 & 5 & 3 & 1 & 2 & 5 & 4 & 5 & 5 & 1 & 5 & 2 & 5 & 0 & \\
\hline Cytophaga johnsonae ATCC 29586 & 5 & 2 & 3 & 1 & 5 & 5 & 3 & 1 & 2 & 5 & 4 & 3 & 3 & 1 & 5 & 2 & 5 & 0 & \\
\hline Cytophaga latercula $\mathrm{NCM}$ & 5 & 2 & 4 & 1 & 5 & 5 & 3 & 5 & 5 & 4 & 4 & 0 & 0 & 0 & 0 & 0 & 0 & 0 & \\
\hline Cytophaga lytica NCMB 142 & 5 & 3 & 4 & 1 & 5 & 4 & 2 & 3 & 1 & 5 & 5 & 1 & 1 & 0 & 3 & 2 & 5 & 2 & \\
\hline Cytophaga salmonicolor NCMB $2216^{\mathrm{T}}$ & 5 & 1 & 2 & 0 & 0 & 0 & 0 & 0 & 4 & 2 & 1 & 3 & 0 & 1 & 5 & 5 & 5 & 0 & \\
\hline "Cytophaga allerginae" ATCC 35408 & 5 & 2 & 4 & 1 & 5 & 5 & 2 & 1 & 3 & 5 & 5 & 3 & 3 & 2 & 5 & 5 & 4 & 0 & \\
\hline Flexibacter aggregans $\mathrm{NCMB} 1443^{\mathrm{T}}$ & 5 & 3 & 4 & 1 & 5 & 4 & 3 & 3 & 0 & 5 & 5 & 1 & 3 & 0 & 4 & 2 & 5 & 3 & \\
\hline Flexibacter aurantiacus NCMB $1382^{\mathrm{T}}$ & 5 & 2 & 4 & 1 & 5 & 5 & 3 & 0 & 0 & 5 & 3 & 0 & 1 & 0 & 5 & 3 & 3 & 0 & \\
\hline Flexibacter aurantiacus & 5 & 2 & 4 & 1 & 5 & 5 & 3 & 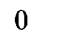 & 0 & 5 & 4 & 0 & 0 & 0 & 5 & 3 & 4 & 0 & \\
\hline Flexibacter car & 5 & 2 & 3 & 1 & 5 & 5 & 3 & 4 & 1 & 5 & 5 & 4 & 1 & 0 & 5 & 3 & 4 & 0 & \\
\hline Flexibacter flexil & 5 & 3 & 4 & 0 & 5 & 4 & 3 & 1 & 2 & 3 & 1 & 0 & 0 & 0 & 3 & 0 & 0 & 0 & \\
\hline Flexibacter litoralis $\mathrm{NCMB} 1366^{\mathrm{T}}$ & 5 & 2 & 4 & 1 & 5 & 5 & 3 & 5 & 1 & 5 & 5 & 0 & 0 & 0 & 0 & 0 & 0 & 0 & \\
\hline Flexibacter polymorphus ATCC 2782 & 5 & 2 & 3 & 1 & 5 & 5 & 3 & 4 & 1 & 2 & 2 & 0 & 0 & 0 & 2 & 0 & 0 & 0 & \\
\hline Flexibacter roseolus NCMB 1 & 4 & 2 & 3 & 1 & 3 & 3 & 2 & 1 & 3 & 2 & 2 & 0 & 0 & 0 & 0 & 0 & 0 & 0 & \\
\hline Flex & 5 & 3 & 4 & 2 & 3 & 3 & 2 & 1 & 3 & 3 & 3 & 0 & 0 & 0 & 0 & 0 & 0 & 0 & \\
\hline Flexibacter sancti $\mathrm{N}$ & 5 & 0 & 2 & 0 & 4 & 1 & 0 & 4 & 0 & 4 & 5 & 4 & 4 & 0 & 4 & 3 & 4 & 0 & \\
\hline Flexibacter tractuosus NCMB $1408^{\mathrm{T}}$ & 5 & 2 & 3 & 1 & 5 & 4 & 3 & 1 & 4 & 5 & 4 & 0 & 0 & 0 & 5 & 1 & 0 & 0 & \\
\hline Flavobacterium aquatile NCIB $8694^{\mathrm{T}}$ & 4 & 2 & 4 & 1 & 5 & 5 & 2 & 0 & 0 & 1 & 2 & 0 & 0 & 0 & 5 & 0 & 0 & 0 & \\
\hline Flavobacterium balustinum LA $724^{\mathrm{T}}$ & 5 & 1 & 2 & 2 & 5 & 5 & 3 & 2 & 1 & 5 & 5 & 0 & 0 & 0 & 3 & 3 & 2 & 0 & \\
\hline Fla & 5 & 3 & 4 & 0 & 5 & 5 & 3 & 3 & 2 & 5 & 5 & 0 & 0 & 0 & 4 & 0 & 0 & 0 & \\
\hline Flavobacterium meningosepticum NCTC $10016^{\mathrm{T}}$ & 5 & 4 & 4 & 3 & 5 & 5 & 5 & 3 & 4 & 4 & 5 & 3 & 0 & 0 & 4 & 2 & 5 & 2 & \\
\hline Flavobacterium odoratum NCTC $11036^{\mathrm{T}}$ & 5 & 2 & 3 & 0 & 2 & 0 & 0 & 1 & 0 & 5 & 5 & 0 & 0 & 0 & 0 & 0 & 0 & 0 & \\
\hline Flavobacterium multivorum NCTC 113 & 5 & 4 & 4 & 1 & 5 & 1 & 1 & 0 & 0 & 5 & 5 & 2 & 4 & 0 & 4 & 3 & 5 & 3 & \\
\hline Flavobacterium spiritivorum $\mathrm{NCTC} 11386^{\mathrm{T}}$ & 5 & 2 & 4 & 0 & 5 & 1 & 1 & 5 & 2 & 5 & 5 & 2 & 4 & 1 & 3 & 2 & 5 & 3 & \\
\hline
\end{tabular}

${ }^{a}$ Abbreviations are explained in Table 1, footnote $a$.

${ }^{b}$ A, 2-Naphthyl-phosphate; B, 2-naphtyl-butyrate; C, 2-naphthyl-caprylate; D, 2-naphthyl-myristate; E, L-leucyl-2-naphthylamide; F, L-valyl-2-naphthylamide; G, L-cystyl-2-naphthylamide; H, N-benzoyl-DL-arginine-2-naphthylamide; I, $N$-glutaryl-phenylalanine-2-naphthylamide; J, 2-naphthyl-phosphate; K, naphtholAS-BI-phosphate; L, 6-Br-2-naphthyl- $\alpha$-D-galactopyranoside; M, 2-naphthyl- $\beta$-D-galactopyranoside; N, naphthol-AS-BI- $\beta$-D-glucuronide; O, 2-naphthyl- $\alpha$ D-glucopyranoside; $\mathrm{P}, 6$-Br-2-naphthyl- $\beta$-D-glucopyranoside; $\mathrm{Q}, 1$-naphthyl- $N$-acetyl- $\beta$-D-glucosaminide; $\mathrm{R}, 6$-Br-2-naphthyl- $\alpha$-D-mannopyranoside; S, 2-naphthyl- $\alpha$-L-fucopyranoside.

$c$ The values 0 to 5 are API reaction scores.

${ }^{d}$ D, Different reactions. Strains NCMB 1038, NCMB $2248^{\mathrm{T}}$, Wakabayashi EK28, TG 39/87, and TG $44 / 87$ gave positive results for substrates H (score 3 ) and I (score 1 or 2 ); other strains gave negative results for both of these substrates.

The properties that were common to the seven strains of "Cytophaga psychrophila" are given below. The following properties varied among the strains: all strains except strain NCMB $1947^{\mathrm{T}}$ produced both compact colonies with regular edges and more or less spreading colonies with uneven margins (strain NCMB $1947^{\mathrm{T}}$ produced only compact colonies); strain TG 28/86 was resistant to kanamycin; strains TG 02/86, LNPAA P01/88, and LNPAA P03/88 were resistant to nalidixic acid; strains TG 28/86 and TG P02/88 were resistant to actinomycin D; and strains TG 02/86, TG 28/86, LNPAA P01/88, TG P02/88, and LNPAA P03/88 were resistant to sulfonamides.

Phenotypic characteristics of Flexibacter maritimus. All of the properties studied were found to be identical among the three Flexibacter maritimus strains and in agreement with the results of Wakabayashi et al. (32). Some additional characteristics are given below.

\section{DISCUSSION}

Although the epithet columnaris has been associated with a fish-pathogenic gliding bacterium since 1922 (9) and has been used in various combinations, including "Bacillus columnaris" (9), "Chondrococcus columnaris" (21), "Cytophaga columnaris" (11), and "Flexibacter columnaris", (16), by fish pathologists for 66 years, no name with this epithet was included on the Approved Lists (30), and no such name has been validated by announcement or publication in the International Journal of Systematic Bacteriology. In this study we found that six strains labeled "Flexibacter columnaris" and two unlabeled isolates constitute a genomic species which can be identified by phenotypic properties. This taxon should be recognized as a species (33), which we call provisionally "species columnaris."

The epithet psychrophila, for an organism belonging to the Cytophaga-Flexibacter-Flavobacterium complex, has been associated with a fish-pathogenic gliding bacterium since 1960 (5) and has been used in the combinations "Cytophaga psychrophila" (5) and "Flexibacter psychrophila"' (sic) (27, 28 ) by fish pathologists for 28 years; this organism has been remarkably characterized by Pacha (23) and by Holt (M.Sc. and Ph.D. theses). No name with this epithet was included on the Approved Lists (30), and no such name has been 
validated since 1980 . In this study we showed that two strains labeled "Cytophaga psychrophila" and five other unlabeled isolates constitute a genomic species which can be identified by phenotypic properties. This organism should be recognized as a species (33), which we call provisionally "species psychrophila."

Strain NCMB 1455 does not belong in species psychrophila. Many phenotypic characteristics of this organism differ from those of the species, and strain NCMB 1455 is only $5 \%$ related to strain NCMB $1947^{\mathrm{T}}$. Strain NCMB 1455 was received from E. J. Ordal as "Cytophaga psychrophila" by Lewin and Lounsbery (18), who classified it as Flexibacter aurantiacus. Results of our DNA study confirmed the opinion of Holt (Ph.D. thesis) that strain NCMB 1455 is not a member of "Cytophaga psychrophila," as demonstrated by serological and biochemical tests.

The name Flexibacter maritimus has been validly published (32). In this study we found that this taxon constitutes a genomic species which can be identified by phenotypic properties, thus justifying the proposal of Wakabayashi et al. (32).

One of the major problems in the taxonomy of the Cytophaga-Flexibacter-Flavobacterium phylogenetic branch (26, 29 ) is the delineation of genera. The ribosomal ribonucleic acid sequence data which have been published are of no help in the delineation of the genus Flexibacter since the only species of that genus which has been studied is an invalid one, "Flexibacter elegans" (24).

The three genomic species which we studied (species columnaris, species psychrophila, and Flexibacter maritimus) are composed of gliding bacteria and thus cannot belong in the genus Flavobacterium (14). Their $\mathrm{G}+\mathrm{C}$ contents are 32 to $33 \mathrm{~mol} \%$, which excludes them from the genus Lysobacter $(\mathrm{G}+\mathrm{C}$ content, around $65 \mathrm{~mol} \%)$ (26). Strict aerobic metabolism is incompatible with inclusion in the genus Capnocytophaga (26). Lack of microcyst production and cellulose digestion is incompatible with inclusion in the genus Sporocytophaga (16). Species columnaris and species psychrophila are neither marine nor halophilic and thus cannot belong in the genus Microscilla (26). Thus, the three genotypic groups which we studied can belong only in the genus Cytophaga or the genus Flexibacter.

Following the opinion of several authors, Leadbetter (16) proposed that the genera Cytophaga and Flexibacter should be differentiated on the basis of polysaccharide degradation (polysaccharides are degraded by Cytophaga species and not by Flexibacter species). Accordingly, the three genomic groups which we studied belong in the genus Flexibacter. Reichenbach and Dworkin (26) have cast doubt on such differentiation. Instead, these authors propose to give more weight to morphological characteristics (members of the genus Cytophaga have short to moderately long rod-shaped cells, some longer nonmotile threads appearing only occasionally in old cultures, whereas Flexibacter species have very long and agile threadlike cells, becoming very short in aging cultures) and to the $\mathrm{G}+\mathrm{C}$ contents of the DNAs (Cytophaga spp., 30 to 35 mol\%; Flexibacter spp., around 48 mol\%). According to these criteria, our three genomic groups do not belong in the genus Flexibacter. However, since cell fragmentation in the late stationary phase is not restricted to the members of the order Cytophagales with high $\mathrm{G}+\mathrm{C}$ contents and is highly dependent on the composition of the medium (15), and since the type species of the genera Cytophaga and Flexibacter have insignificantly different $\mathrm{G}+\mathrm{C}$ contents (Cytophaga hutchinsonii, 39 to 40 mol\% [6, 15]; Flexibacter flexilis, 39 to $44 \mathrm{~mol} \%$ [19; $\mathrm{H}$.
Behrens, Ph.D. thesis, Technical University Braunschweig, Braunschweig, Federal Republic of Germany, 1978]), these arguments are weakened.

It is obvious that more work is needed to define the genera in the Cytophaga-Flexibacter-Flavobacterium phylogenetic branch. At the present state of knowledge, we propose that species columnaris and species psychrophila should be included in the genus Flexibacter, as Flexibacter columnaris and Flexibacter psychrophilus, pending further reorganization of the whole phylogenetic branch. Nine years have elapsed since the publication of the Approved Lists, and Flexibacter columnaris and Flexibacter psychrophilus (in these or other combinations) have not yet been validated. Such validation is formally proposed below.

Description of Flexibacter columnaris sp. nov., nom. rev. (ex Leadbetter 1974). Flexibacter columnaris (basionym, " $\mathrm{Ba}$ cillus columnaris" Davis 1922) (co.lum.nar'is. L. adj. columnaris, rising as a pillar). The description below is based on eight strains and also includes data collected by Leadbetter (16) and Becker and Fujihara (3). Cells are nonsporulating, nonmotile, gram-negative rods that are 3 to $10 \mu \mathrm{m}$ long by 0.3 to $0.5 \mu \mathrm{m}$ wide in 48 -h liquid cultures; some longer cells $(15$ to $25 \mu \mathrm{m})$ may occur. No formation of microcysts. In older cultures, spherical degenerative forms (spheroplasts) may appear. A clear gliding movement, as well as bending and pivoting, occur in hanging-drop preparations. Grows in Anacker-Ordal broth (2) supplemented with 0 or $0.5 \% \mathrm{NaCl}$ and at 10 to $33^{\circ} \mathrm{C}$; some strains tolerate $37^{\circ} \mathrm{C}$, but the optimum temperature is 20 to $25^{\circ} \mathrm{C}$. No growth in Trypticase soy broth. Colonies on Anacker-Ordal agar are flat, thin, spreading, greenish yellow, more or less rhizoid, and adherent to the agar. In shaken liquid cultures, numerous filamentous tufts of bacteria adhere to the glass. Nondiffusible flexirubin type pigments are present. Congo red is absorbed by colonies. Strictly aerobic. Catalase and cytochrome oxidase are produced. Nitrate is reduced to nitrite; nitrite is not reduced. Hydrogen sulfide is produced. $o$ Nitrophenyl- $\beta$-D-galactopyranoside is not hydrolyzed. Cellulose, carboxymethyl cellulose, chitin, starch, esculin, and agar are not hydrolyzed. No acid is produced from carbohydrates in ammonium salt-sugar medium (API 50CH galleries). Gelatin, casein (skim milk agar), and tyrosine are hydrolyzed. Lysine, arginine, and ornithine are not decarboxylated. Tributyrin, lecithin (egg yolk), Tween 20, and Tween 80 are hydrolyzed. Rapid and intense DNA hydrolysis. No inhibition zone is formed around the following types of disks (the concentration in each type of disk is indicated in parentheses): gentamicin $(15 \mu \mathrm{g})$, neomycin $(30 \mu \mathrm{g})$, kanamycin $(30 \mu \mathrm{g})$, polymyxin $\mathrm{B}(30 \mu \mathrm{g})$, trimethoprim $(5 \mu \mathrm{g})$, and actinomycin D $(2.5 \mu \mathrm{g})$. Susceptible (inhibition zone, more than $9 \mathrm{~mm})$ to vibriostatic compound $\mathrm{O} / 129(500 \mu \mathrm{g})$, ampicillin $(10 \mu \mathrm{g})$, cephalothin $(30 \mu \mathrm{g})$, streptomycin (10 IU), tetracycline ( $30 \mathrm{IU})$, chloramphenicol $(30 \mu \mathrm{g})$, erythromycin (15 IU), novobiocin (30 IU), nalidixic acid (30 $\mu \mathrm{g})$, and furans $(300 \mu \mathrm{g})$. Hydrolyzes the following substrates (API ZYM galleries): 2-naphthyl-phosphate (at $\mathrm{pH} 8.5$ and 5.4), 2-naphthyl-butyrate, 2-naphthyl-caprylate, L-leucyl-2-naphthylamide, L-valyl-2-naphthylamide, and naphthol-AS-BIphosphate. Does not hydrolyze the following substrates (API ZYM galleries): 2-naphthyl-myristate, L-cystyl-2-naphthylamide, 6-Br-2-naphthyl- $\alpha$-D-galactopyranoside, 2-naphthyl$\beta$-D-galactopyranoside, naphthol-AS-BI- $\beta$-D-glucuronide, 2-naphthyl- $\alpha$-D-glucopyranoside, 6 - $\mathrm{Br}$-2-naphthyl- $\beta$-D-glucopyranoside, 1 -naphthyl- $N$-acetyl- $\beta$-D-glucosaminide, 6$\mathrm{Br}-2$-naphthyl- $\alpha$-D-mannopyranoside, and 2-naphthyl- $\alpha-\mathrm{L}-$ fucopyranoside. 
The base composition of the DNA is 32 to $33 \mathrm{~mol} \% \mathrm{G}+\mathrm{C}$ (three strains). All strains were isolated from freshwater fish suffering from columnaris disease in North America, Europe, and Japan.

The type strain is strain NCMB 2248 (= ATCC 23463).

Description of the type strain. Strain NCMB $2248^{\mathrm{T}}$ has all of the characteristics given above for the species. In addition, it produces very rhizoid and strongly adherent colonies on Anacker-Ordal agar, but some less rhizoid and more spreading colonies may appear. Does not produce a brown color on tyrosine agar. Resistant to sulfonamides $(200-\mu \mathrm{g}$ disks). Hydrolyzes $N$-benzoyl-DL-arginine-2-naphthylamide and $N$-glutaryl-phenylalanine-2-naphthylamide in API ZYM galleries. No growth occurs at temperatures above $33^{\circ} \mathrm{C}$; weak growth occurs at $15^{\circ} \mathrm{C}$. The base composition of the type strain is $32 \mathrm{~mol} \% \mathrm{G}+\mathrm{C}$.

Description of Flexibacter psychrophilus sp. nov., nom. rev. Flexibacter psychrophilus (basionym, "Cytophaga psychrophila" ex Borg 1960) (psy.chro'phil.us Gr. adj. psychros, cold; Gr. adj. philos, loving; M.L. adj. psychrophilus, cold loving). The description below is based on seven strains and also includes data from Borg (5), Pacha (23), and Holt (M.Sc. and $\mathrm{Ph} . \mathrm{D}$. theses). Cells are nonsporulating, nonmotile, gram-negative rods that are 1 to $5 \mu \mathrm{m}$ long by 0.3 to $0.5 \mu \mathrm{m}$ wide in 48-h liquid cultures; a few longer cells ( 8 to $12 \mu \mathrm{m}$ ) may appear. Some cells have an enlarged end. In hangingdrop preparations, the gliding movement is frequently slow and weak and is noticed after prolonged observation. Some strains exhibit faster gliding. Good growth occurs in Anacker-Ordal broth (2) supplemented with 0 or $0.5 \% \mathrm{NaCl}$ and at 10 to $20^{\circ} \mathrm{C}$. The optimum temperature is 15 to $18^{\circ} \mathrm{C}$, and scant, slow growth occurs at 6 and 22 to $25^{\circ} \mathrm{C}$. No growth occurs in Trypticase soy broth. Growth on AnackerOrdal agar is enhanced by an enriched formula $(0.5 \%$ tryptone instead of $0.05 \%$ tryptone). Most colonies are smooth, glossy, and circular with regular edges, but most strains can also produce colonies with narrow and uneven spreading margins. The colonies are bright yellow and do not adhere to the agar. Nondiffusible flexirubin type pigments are present. Colonies do not absorb Congo red. Strictly aerobic. Catalase and cytochrome oxidase are produced. Nitrate is not reduced, and hydrogen sulfide is not produced. $o$-Nitrophenyl$\beta$-D-galactopyranoside is not hydrolyzed. Cellulose, carboxymethyl cellulose, chitin, starch, esculin, and agar are not hydrolyzed. No acid is produced from carbohydrates in ammonium salt-sugar medium (API 50CH galleries). Gelatin, casein (skim milk agar), and tyrosine are hydrolyzed. No brown color is produced on tyrosine agar. Lysine, arginine, and ornithine are not decarboxylated. Tributyrin, lecithin (egg yolk), Tween 20, and Tween 80 are hydrolyzed. Weak, slow DNA hydrolysis. No inhibition zone is formed around the following types of disks (the concentration in each type of disk is indicated in parentheses): gentamicin $(15 \mu \mathrm{g})$, neomycin $(30 \mu \mathrm{g})$, polymyxin B (30 $\mu \mathrm{g})$, and trimethoprim (5 $\mu \mathrm{g}$ ). Susceptible (inhibition zone, more than $9 \mathrm{~mm}$ ) to vibriostatic compound $\mathrm{O} / 129(500 \mu \mathrm{g})$, ampicillin $(10 \mu \mathrm{g})$, cephalothin $(30 \mu \mathrm{g})$, streptomycin (10 IU), tetracycline (30 IU), chloramphenicol ( $30 \mu \mathrm{g})$, erythromycin (15 IU), novobiocin (30 IU), and furans $(300 \mu \mathrm{g})$. Hydrolyzes the following substrates (API ZYM galleries): 2-naphthyl-phosphate (at pH 8.5 and 5.4), 2-naphthyl-butyrate, 2-naphthyl-caprylate, L-leucyl-2-naphthylamide, L-valyl-2-naphthylamide, and naphthol-AS-BI-phosphate. Does not hydrolyze the following substrates (API ZYM galleries): 2-naphthyl-myristate, L-cystyl-2-naphthylamide, $N$-benzoyl-DL-arginine-2-naphthylamide, $\mathrm{N}$-glutaryl-phenylalanine-2-naphthylamide, 6 - $\mathrm{Br}$ - 2-naphthyl- $\alpha$-D-galactopyranoside, 2 -naphthyl- $\beta$-D-galactopyranoside, naphthol-AS-BI- $\beta$-D-glucuronide, 2-naphthyl$\alpha$-D-glucopyranoside, 6-Br-2-naphthyl- $\beta$-D-glucopyranoside, 1 -naphthyl- $N$-acetyl- $\beta$-D-glucosaminide, 6-Br-2-naphthyl- $\alpha$ D-mannopyranoside, and 2-naphthyl- $\alpha$-L-fucopyranoside.

The base composition is 32.5 to $34 \mathrm{~mol} \% \mathrm{G}+\mathrm{C}$ (three strains).

All strains were isolated from freshwater fish suffering from cold-water disease in North America and France.

The type strain is strain NCMB 1947.

Description of the type strain. Strain NCMB $1947^{\mathrm{T}}$ has all of the characteristics given above for the species. In addition, it produces round colonies with regular edges. Colonies with narrow spreading margins are sometimes produced. The gliding movement is very slow. Susceptible (inhibition zone, more than $9 \mathrm{~mm}$ ) to kanamycin $(30 \mu \mathrm{g})$, sulfonamides $(200 \mu \mathrm{g})$, nalidixic acid $(30 \mu \mathrm{g})$, and actinomycin D $(2.5 \mu \mathrm{g})$. The base composition of the type strain is $32.5 \mathrm{~mol} \%$ $\mathrm{G}+\mathrm{C}$.

Addendum to the description of Flexibacter maritimus. In addition to the original description (32), the characteristics given below may be useful in identification. $o$-Nitrophenyl$\beta$-D-galactopyranoside is not hydrolyzed. Agar is not hydrolyzed. No acid is produced from carbohydrates in ammonium salt-sugar medium (API $50 \mathrm{CH}$ galleries). A brown color is produced on tyrosine agar. Lecithin (egg yolk), Tween 20, and Tween 80 are hydrolyzed. Weak, slow DNA hydrolysis. No inhibition zone is formed around the following types of disks (the concentration in each type of disk is indicated in parentheses): gentamicin $(15 \mu \mathrm{g})$, neomycin (30 $\mu \mathrm{g})$, kanamycin $(30 \mu \mathrm{g})$, streptomycin (10 IU), polymyxin B $(30 \mu \mathrm{g})$, actinomycin D $(2.5 \mu \mathrm{g})$, and nalidixic acid $(30 \mu \mathrm{g})$. Susceptible (inhibition zone, more than $9 \mathrm{~mm}$ ) to vibriostatic compound $\mathrm{O} / 129$, ampicillin $(10 \mu \mathrm{g})$, cephalothin $(30 \mu \mathrm{g})$, tetracycline (30 IU), chloramphenicol $(30 \mu \mathrm{g})$, erythromycin (15 IU), novobiocin (30 IU), sulfonamides $(200 \mu \mathrm{g})$, trimethoprim $(5 \mu \mathrm{g})$, and nitrofurans $(300 \mu \mathrm{g})$. The following substrates are hydrolyzed (API ZYM galleries): 2-naphthylphosphate (at pH 8.5 and 5.4), 2-naphthyl-butyrate, 2-naphthyl-caprylate, L-leucyl-2-naphthylamide, L-valyl-2-naphthylamide, L-cystyl-2-naphthylamide, $N$-benzoyl-DL-arginine-2naphthylamide, $N$-glutaryl-phenylalanine-2-naphthylamide, and naphthol-AS-BI-phosphate. Does not hydrolyze the following substrates (API ZYM galleries): 2-naphthyl-myristate, 6-Br-2-naphthyl- $\alpha$-D-galactopyranoside, 2-naphthyl- $\beta$-D-galactopyranoside, naphthol-AS-BI- $\beta$-D-glucuronide, 2-naphthyl$\alpha$-D-glucopyranoside, 6-Br-2-naphthyl- $\beta$-D-glucopyranoside, 1-naphthyl- $N$-acetyl- $\beta$-D-glucosaminide, 6-Br-2-naphthyl- $\alpha$ D-mannopyranoside, and 2-naphthyl- $\alpha$-L-fucopyranoside.

\section{ACKNOWLEDGMENTS}

We thank R. A. Holt (Oregon State University, Corvallis), H. Wakabayashi (Faculty of Agriculture, Tokyo, Japan), J. Farkas (Fisheries Research Institute, Szarvas, Hungary), and F. BaudinLaurencin (Laboratoire National de Pathologie des Animaux Aquatiques, Brest, France) for supplying several strains included in this study. J.F.B. thanks L. Le Minor for hospitality in the Unité des Entérobactéries (Institut Pasteur, Paris). We acknowledge the excellent technical assistance of E. Ageron and B. Kerouault. We also thank M. C. Le Cochennec for typing the manuscript.

This work was supported by grant 88003 from the Conseil Supérieur de la Pêche.

\section{LITERATURE CITED}

1. Amend, D. F. 1982. Columnaris (Flexibacter columnaris) disease of freshwater fishes and a brief review of other flexibacte- 
rial diseases of fish, p. 139-151. In D. P. Anderson, M. Dorson, and P. Dubourget (ed.), Antigens of fish pathogens. Symposium International de Talloires. Collection Fondation Marcel Mérieux, Lyon.

2. Anacker, R. L., and E. J. Ordal. 1955. Study of a bacteriophage infecting the myxobacterium Chondrococcus columnaris. J. Bacteriol. 70:738-741.

3. Becker, C. D., and M. P. Fujihara. 1978. The bacterial pathogen Flexibacter columnaris and its epizootiology among Columbia River fish. A review and synthesis. Monograph no. 2. American Fisheries Society, Washington, D.C.

4. Bernardet, J. F. 1989. "Flexibacter columnaris": first description in France and comparison with bacterial strains from other origins. Dis. Aquat. Org. 6:37-44.

5. Borg, A. F. 1960. Studies on myxobacteria associated with diseases in salmonid fishes. J. Wildl. Dis. 8:1-85. (Two microcards.)

6. Brenner, D. J., A. C. McWhorter, J. K. Leete Knutson, and A. G. Steigerwalt. 1982. Escherichia vulneris: a new species of Enterobacteriaceae associated with human wounds. J. Clin. Microbiol. 15:1133-1140.

7. Callies, E., and W. Mannheim. 1980. Deoxyribonucleic acid relatedness of some menaquinone-producing Flavobacterium and Cytophaga strains. Antonie van Leeuwenhoek J. Microbiol. Serol. 46:41-49.

8. Campbell, A. C., and J. A. Buswell. 1982. An investigation into the bacterial aetiology of "black patch necrosis" in Dover sole (Solea solea L.). J. Fish Dis. 5:495-508.

9. Davis, H. S. 1922. A new bacterial disease of fresh-water fishes. Bull. U.S. Bur. Fish. 38:261-280.

10. Davis, H. S. 1946. Care and diseases of trout. Research report no. 12. U.S. Fish and Wildlife Service, Washington, D.C.

11. Garnjobst, L. 1945. Cytophaga columnaris (Davis) in pure culture: a myxobacterium pathogenic to fish. J. Bacteriol. 49:113-128.

12. Grimont, P. A. D., M. Y. Popoff, F. Grimont, C. Coynault, and M. Lemelin. 1980. Reproducibility and correlation study of three deoxyribonucleic acid hydridization procedures. Curr. Microbiol. 4:325-330.

13. Holmes, B. 1987. International Committee on Systematic Bacteriology Subcommittee on the Taxonomy of Flavobacterium and Cytophage-like Bacteria minutes of the meeting, $10 \mathrm{Sep}$ tember 1986, Manchester, England. Int. J. Syst. Bacteriol. 37:301.

14. Holmes, B., R. J. Owen, and T. A. McMeekin. 1984. Genus Flavobacterium, p. 353-360. In N. R. Krieg (ed.), Bergeys' manual of systematic bacteriology, vol. 1. The Williams \& Wilkins Co., Baltimore.

15. Humphrey, B. A., and K. C. Marshall. 1980. Fragmentation of some gliding bacteria during the growth cycle. J. Appl. Bacteriol. 49:281-289.

16. Leadbetter, E. R. 1974. Order II. Cytophagales nomen novum, p. 99. In R. E. Buchanan and N. E. Gibbons (ed.), Bergey's manual of determinative bacteriology, 8 th ed. The Williams \&
Wilkins Co., Baltimore.

17. Lewin, R. A. 1974. Flexibacter polymorphus, a new marine species. J. Gen. Microbiol. 82:393-403.

18. Lewin, R. A., and D. M. Lounsbery. 1969. Isolation, cultivation, and characterization of flexibacteria. J. Gen. Microbiol. 58: 145-170.

19. Mandel, M., and R. A. Lewin. 1969. Deoxyribonucleic acid base composition of flexibacteria. J. Gen. Microbiol. 58:171-178

20. Marmur, J., and P. Doty. 1962. Determination of the base composition of deoxyribonucleic acid from its thermal denaturation temperature. J. Mol. Biol. 5:109-118.

21. Ordal, E. J., and R. R. Rucker. 1944. Pathogenic myxobacteria. Proc. Soc. Exp. Biol. Med. 56:15-18.

22. Owen, R. J., L. R. Hill, and S. P. Lapage. 1969. Determination of DNA base compositions from melting profiles in dilute buffers. Biopolymers 7:503-516.

23. Pacha, R. E. 1968. Characteristics of Cytophaga psychrophila (Borg) isolated during outbreaks of bacterial coldwater disease. Appl. Microbiol. 16:97-101.

24. Paster, B. J., W. Ludwig, W. G. Weisburg, E. Stackebrandt, R. B. Hespell, C. M. Hahn, H. Reichenbach, K. O. Stetter, and C. R. Woese. 1985. A phylogenetic grouping of the Bacteroides, cytophagas, and certain flavobacteria. Syst. Appl. Microbiol. 6:34-42.

25. Reichenbach, H., and M. Dworkin. 1981. Introduction to the gliding bacteria, p. 315-327. In M. P. Starr et al. (ed.), The prokaryotes, vol. 1. Springer-Verlag, New York.

26. Reichenbach, H., and M. Dworkin. 1981. The order Cytophagales (with addenda on the genera Herpetosiphon, Saprospira, and Flexithrix), p. 356-379. In M. P. Starr et al. (ed.), The prokaryotes, vol. 1. Springer-Verlag, New York.

27. Richards, R. H., and R. J. Roberts. 1978. The bacteriology of teleosts, p. 183-204. In R. J. Robers (ed.), Fish pathology. Bailliere Tindall, London.

28. Schneider, R., and B. L. Nicholson. 1980. Bacteria associated with fin rot disease in hatchery-reared Atlantic Salmon (Salmo salar). Can. J. Fish. Aquat. Sci. 37:1505-1513.

29. Shewan, J. M., and T. A. MeMeekin. 1983. Taxonomy (and ecology) of Flavobacterium and related genera. Annu. Rev. Microbiol. 37:233-252.

30. Skerman, V. B. D., V. McGowan, and P. H. A. Sneath. (ed.). 1980. Approved lists of bacterial names. Int. J. Syst. Bacteriol. 30:225-420.

31. Wakabayashi, H., M. Hikida, and K. Masumura. 1984. Flexibacter infection in cultured marine fish in Japan. Helgol. Meeresunters. 37:587-593.

32. Wakabayashi, H., M. Hikida, and K. Masumura. 1986. Flexibacter maritimus $\mathrm{sp}$. nov., a pathogen of marine fishes. Int. J. Syst. Bacteriol. 36:396-398.

33. Wayne, L. G., D. J. Brenner, R. R. Colwell, P. A. D. Grimont, O. Kandler, M. I. Krichevsky, L. H. Moore, W. E. C. Moore, R. G. E. Murray, E. Stackebrandt, M. P. Starr, and H. G. Trüper. 1987. Report of the Ad Hoc Committee on Reconciliation of Approaches to Bacterial Systematics. Int. J. Syst. Bacteriol. 37:463-464. 